\title{
Is TV Increasing Aggression in Secondary School Students: An Enquiry?
}

\author{
Ravi Kant ${ }^{1}$ \\ ${ }^{1}$ Department of Education \& Training, Maulana Azad National Urdu University, Hyderabad, India \\ Correspondence: Ravi Kant, Assistant Professor, Maulana Azad National Urdu University, College of Teacher \\ Education, Darbhanga - 846001, Bihar, India. Tel: 91-06272-277616. E-mail: edu.ravikant@gmail.com
}

Received: January 28, 2016

Accepted: February 1, 2016

Online Published: February 29, 2016

doi:10.20849/aes.v1i1.31

URL: http://dx.doi.org/10.20849/aes.v1i1.31

\begin{abstract}
Entire generation is growing with media i.e. mobile and TV etc. Television is the powerful medium of communication with a tremendous potency to inform to entertain and to educate. Its expansion has been more dramatic than that to radio or the automobile. It has become an important part of our life, so much that it is difficult to say whether it is a luxury or necessity." India is a developing country and its selections are different in culture, ideas the way of living and thinking too. Teenagers are the backbone of the country to form a place worthy citizen. They are too tender to motivate by any act or deed. Social activists, Educationists are debating whether Television is increasing aggression of students. By taking 200 sample of secondary school students with the help of one standardized and one self-made tool, an attempt has made to explore relationship between TV viewing and aggression. Survey method was used. Investigation find there slightly difference in TV viewing of male and female students. Male students found more aggressive in comparison of their counterpart i.e. females. Television viewing has a slight effect on aggression of students but statistically it found non-significant.
\end{abstract}

Keywords: television viewing habits, aggression, secondary school students

\section{Introduction}

Now in India children is growing up with several electronic device such as mobile, television, computer etc. Day by day television become more versatile and effective. Initial stage television used some limited purposes but due to effectiveness of TV this instrument using in every house. Due to its versatility and effectiveness it is considered and called as Window of the world. It is a question of debate for a long time that TV has negative impact on children's mind.

Several studies have done on television and it relation with aggression. And when we want to know about them we consider several theories and concepts, which have been employed to deepen our understanding of the link between media violence and aggression. According to Social Learning Theory by Albert Bandura media characters may serve as models for aggressive behavior. Imitation of violent behavior is supposed to be more likely when aggressive models are rewarded (e.g., they obtain money, love, or respect). When aggressive behaviors are penalized (e.g., violent characters lose respect or get arrested) imitation of violent behavior is supposed to be less likely (Bandura et al., 1963).

Ever since Bandura's classical early studies on imitation of film violence (Bandura et al., 1963), laboratory experiments have played an important role in showing that exposure to violent media causes a short - term increase in aggressive behavior. There can no longer be any dispute about this conclusion, and more recent studies using more valid measures of aggression have shown similar results.

In a study, researchers showed 58 preschoolers two pictures from cartoons and two cartoon video clips and then asked what the child thought would happen next. A parent survey of the child's television exposure and behaviors was also taken and researchers found that children who had been exposed to violent television shows tended to predict violent endings to the cartoon pictures and video clips when asked what they thought would happen next. These results indicate that even mere exposure to cartoon violence can cause children to develop aggressive mental models that are used even when aggression isn't present. (Krcmar \& Hight, 2007)

Exposure of violent media and TV programs certainly rise the aggressiveness of child and adolescent when they regularly watch the violent programs, they want to act according to the main character of programs and accept 
the ideology of that character, There is a growing consensus within the social sciences that exposure to violent media increases aggression (Anderson \& Bushman, 2002a; Bushman \& Anderson, 2001).

Behaviors of three hundred and seventy-six preschoolers by looking at child development supplement questionnaires, time diaries, and a behavior problem index. Five years later, when the children were between the ages of seven and ten, behavior was measured again and the researchers found that watching violent television between the ages of 2-4 was significantly associated with antisocial behaviors such as cheating and "being mean to others" when the child was 7-9 years old. However, this association was only found for boys. The researchers in this study attributed this gender difference in behavior to socialization differences between genders. (Dmitri \& Zimmerman, 2007)

Based on the Excitation Transfer Theory put forward by Dolf Zillmann, it has been assumed that "violent media increase an individual's arousal which amplifies any emotional and behavioral tendency. The arousal is supposed to be unspecific, thus it may intensify anger and aggressive behavior or joy and non-aggressive behavior depending upon the context present after violent media exposure" (Zillmann, 1998).

"Most of the findings from these studies point in the same direction (i.e., exposure to media violence is related to increased aggression), a number of researchers have questioned the practical significance of these findings. Specifically, causal ambiguities, the modest size of the effects and the restricted generalize ability of the dependent variables have led scholars to question whether, in fact, these findings have any bearing on the commission of a violent crime. Comstock, for example, concluded that the link between media violence and criminal activity".

"When media messages match real-world family experiences, the media depictions might not be cataloged as "fictional" or "deviant" but, instead, associated with "real life" memory units (such as "how Mom and Dad resolve disputes"). This formulation is congruent with Geen's (1983) and Huesmann's (1982) suggestions that events that are perceived as real rather than fictional might be more salient and therefore more likely to be encoded, leading to greater probability of later retrieval and possible behavioral effects " (Heath, Kruttschnitt, Wardf, 1986).

"Aggression is most likely to develop in children who grew up in environment that reinforce aggression provide aggressive models, frustrate and victimize them, and teach them that aggression is acceptable." (The Sage handbook of Social Psychology).

"By the age of 18 an American child will have seen 16000 acts simulated murders and 200000 acts of violence, more than 1000 on the effects of television and film violence has been done over the past 40 years. The majority of these studies reach the same conclusions, television and film violence leads to real world violence." (Children violence and the media-senate committee on the judiciary)

"Although the scientific evidence shows that violent media effects are undeniable, many people still deny these effects".

\subsection{Objectives of the Study}

- To study the television viewing patterns of secondary school students.

- To study the aggressive behavior of secondary school students.

- To study the relationship of television viewing on aggressive behavior of secondary school students.

\subsection{Hypotheses}

1. There will be no differences in TV viewing patterns among secondary school students.

2. There will be no significance difference in aggressive behavior of secondary school students on the basis of gender and locality.

3. There will be no effect of television viewing on aggressive behavior of secondary school students.

\section{Research Design}

\subsection{Research Method}

In the execution of the present study, descriptive survey method of research is employed. This method has been the most popular and the most widely used research method in social sciences. 


\subsection{Population \& Sample}

In this study all secondary school students of Darbhanga city constitutes as population. From this population 200 students selected randomly by keeping A stratified random sample was drawn from this population, which consisted of 200 secondary school students giving due representation on the basis of gender and locality.

\subsection{Instruments Used}

Aggression scale (A-scale): This scale was developed by Km. Roma Pal and Mrs. Tasneem Naqvi. It consist 30 items related to aggressive behavior. Each of the item has five alternate answers (multiple choice) graded on five point scale on the positive dimension. All the items of this aggression scale are matter of behavior in daily life.

Television viewing habits related questionnaire: This tool was developed by the investigator under the guidance of his guide. It consist 10 items related with Television viewing habits of especially secondary school students. All items has multiple choice answers. In this tool a general information blank is given on the top of the tool. It was used to get demographic information of the students like age, class, location of school, name, gender, father's name, name of the school etc.

\section{Data Analysis \& Interpretation}

The main objective of the study is to find out the television-viewing pattern of secondary school students, the aggressive behavior of secondary school students and to know how television viewing pattern influences on their aggression. This study is planned and carried out to test the assumptions and tentative well hypotheses which may be accepted or rejected. The analyses has been done in three phases:

1) Television viewing pattern of secondary school students.

2) Aggression behavior of secondary school students.

3) Impact of television-viewing pattern on aggression of secondary school students.

The interpretations of results are discussed simultaneously.

\subsection{Television Viewing Pattern of Students}

Hypothesis 1: There will be no differences in TV viewing patterns among secondary school students.

\subsubsection{Hours of Television}

Table 1. Description of hours spend in television viewing

\begin{tabular}{lll}
\hline Hours of television viewing & Male $(\mathrm{N}=100)$ & Female $(\mathrm{N}=100)$ \\
\hline $0-2$ & 72 & 62 \\
$2-4$ & 26 & 34 \\
$4-6$ & 2 & 4 \\
\hline
\end{tabular}

Table 1 shows that most of the boys $72 \%$ watch the television $0-2$ hours per day, $26 \%$ boys' watch the television 2-4 hours per day and only $2 \%$ boys are heavy television viewer with the timing of $4-6$ per day. On the other hand most of the girls $62 \%$ are also in the category of $2-4$ hours television viewing per day, $34 \%$ girls watch the television 2-4 hours per day and only 4\% girls are heavy television viewer with the timing of 4-6 per day but the girls ratio of heavy television watcher is just double, compared to the boys. It may be due to some sociological barriers for the girls in Indian society. They are restricted to go outside from the home so there is only TV which can give him information about the society and world.

\subsubsection{Number of Television Sets}

Table 2. Description of number of television sets availability

\begin{tabular}{lll}
\hline Number of Television sets & Male $(\mathrm{N}=100)$ & Female $(\mathrm{N}=100)$ \\
\hline 1 set of Television & 94 & 94 \\
2 sets of Television & 6 & 6 \\
\hline
\end{tabular}


Table 2 shows 94\% boys in secondary school students have only one television set in their home, and rest $6 \%$ have two television sets, and this is also found in girls cases. So the large numbers of secondary school students have only one television set available in their home.

\subsubsection{Parental Guidance}

Table 3. Description of status of parental guidance by male and female

\begin{tabular}{lll}
\hline Parental guidance & Male $(\mathrm{N}=100)$ & Female $(\mathrm{N}=100)$ \\
\hline Always & 8 & 8 \\
Mostly & 10 & 16 \\
Never & 24 & 6 \\
Sometime & 58 & 70 \\
\hline
\end{tabular}

Table 3 shows that parental guidance is, always available for only $8 \%$ boys in the secondary school, mostly with $10 \%$ and the large number of boys $58 \%$ had parental guidance available for some times, boys had never parental guidance is $24 \%$ and on the other hand parental guidance is, always available for only $8 \%$ girls in the secondary school, mostly with $10 \%$ and the large number of girls $70 \%$ also had parental guidance available for some times, girls had never parental guidance is very low and it is only $6 \%$. Boys are comparatively freer to watch Television in comparison to girls.

\subsubsection{Favorite Categories of Television Programs}

Table 4. Description of favorite categories of television programs

\begin{tabular}{lll}
\hline Favorite categories of television programs & Male $(\mathrm{N}=100)$ & Female $(\mathrm{N}=100)$ \\
\hline Educational & 60 & 36 \\
Entertainment & 28 & 32 \\
General Informational & 12 & 32 \\
\hline
\end{tabular}

Table 4 shows that in the secondary school, 60\% boy's favorite Television Program is Educational, 28\% boy's favorite Television Program is Entertainment and 12\% boy's favorite Television Program is General informational. And in the case of girls, 36\% girls liked the Educational television program, 32\% liked Entertainment and 32\% liked the General informational Television Program. It is clear by data that maximum boys watched TV for education purpose on other hand they are left behind on watching for general information.

\subsubsection{Cause of Television Watching}

Table 5. Description of cause of television watching programs

\begin{tabular}{lll}
\hline Cause of television watching & Male $(\mathrm{N}=100)$ & Female $(\mathrm{N}=100)$ \\
\hline Entertainment & 14 & 16 \\
Information & 64 & 30 \\
Learning & 22 & 52 \\
Time pass & 0 & 2 \\
\hline
\end{tabular}

Table 5 shows that, $14 \%$ boy causes of television watching is entertainment, most of the boy $64 \%$ watching television to obtain information and $22 \%$ boy watching television to learn something. Girls are different with $16 \%$ causes for watching television is entertainment, information is the reason behind to watch television in $30 \%$ cases and $52 \%$ girl watching television to learn something. Surprisingly $2 \%$ girls watching televisions for time pass. Data clears that both boys and girls. 


\subsubsection{Favorite News Programs}

Table 6. Description of favorite news programs

\begin{tabular}{lll}
\hline Favorite news programs & Male $(\mathrm{N}=100)$ & Female $(\mathrm{N}=100)$ \\
\hline Sports News & 42 & 34 \\
Political News & 32 & 36 \\
Sensational News & 18 & 18 \\
Weather News & 8 & 12 \\
\hline
\end{tabular}

Table 6 shows that $42 \%$ boys in secondary schools Favorite News Programs is sports news, $32 \%$ Favorite News Program is political news, sensational news is the choice of $18 \%$ boys and rest $8 \%$ like weather news. $34 \%$ girls in secondary schools Favorite News Programs is sports news, 36 \% Favorite News Program is political news, sensational news is the choice of $18 \%$ girls and rest $12 \%$ like weather news. On average political news is central news viewing of TV, it means secondary school students are much aware about political awareness.

\subsection{Aggression of Secondary School Students}

Hypothesis 2: There will be no significance difference in aggressive behavior of secondary school students on the basis of gender and locality.

Table 7. Description of the aggression score on the basis of gender

\begin{tabular}{lllll}
\hline VARIABLE & $\mathrm{N}$ & $\mathrm{M}$ & $\mathrm{S} . \mathrm{D}$. & t-value \\
\hline Male & 100 & 69.88 & 22.35 & $0.122^{* *}$ \\
Female & 100 & 62.44 & 25.28 & \\
\hline
\end{tabular}

**Not significant at 0.5 level

Table 7 reveals that mean of aggression scores of secondary school student on the basis of gender. Boys' aggression scores mean (M) is 69.88 and standard deviation (S.D) is 22.35. Girls aggression score mean (M) is 62.44 and standard deviation (S.D) is 25.28. On comparing these mean values, no significant difference is yielded $(\mathrm{t}=0.122, \mathrm{P}=.05$ and. 01$)$. It indicates clearly that there is no significant difference found in aggressive behavior between boys and girls in secondary school.

But the mean values of boys aggression score are more than girls, this shows that boys are more aggressive than girls. Aggression is mainly a characteristic shown by males in animal society included human society, females generally not violent in nature except special cases like attack on their child or mates etc. students are also from there, but the scores clearly shows that aggression level of females are not much less than males in any respective.

Table 8. Description of the aggression score on the basis of locality

\begin{tabular}{lllll}
\hline VARIABLE & $\mathrm{N}$ & $\mathrm{M}$ & $\mathrm{S} . \mathrm{D}$ & t-value \\
\hline Urban & 100 & 77.30 & 24.15 & $1.041^{* *}$ \\
Rural & 100 & 55.02 & 18.18 & \\
\hline
\end{tabular}

** Not significant at 0.5 level

Table 8 reveals the mean of aggression scores of secondary school student on the basis of locality. Urban student's aggression scores mean (M) is 77.30 and standard deviation (S.D) is 24.15. Rural student's aggression score mean (M) is 55.02 and standard deviation (S.D) is 18.18.On comparing these mean values, no significant difference is yielded $(\mathrm{t}=1.041, \mathrm{P}=.05$ and. 01$)$. It indicates clearly that there is no significant difference found in aggressive behavior between secondary school on the basis of locality. 
But the mean values of aggression score of urban secondary school students is more than rural secondary school students, this shows that urban secondary school students are more aggressive than rural secondary school students. It may due to some environmental factors because even today Indian rural areas are free from pollution, infiltration of food etc.

\subsection{Television Viewing and Aggression}

Hypothesis 3: There will be no effect of television viewing on aggressive behavior of secondary school students.

3.3.1 On the basis of number of hour of television watching

Table 9. Description of aggression score on the basis of number of hours of television watching

\begin{tabular}{llll}
\hline Number of hour of television watching & N & M & S.D \\
\hline 0-2 hours & 134 & 62.35 & 22.47 \\
2-4 hours & 60 & 72.60 & 25.44 \\
4-6 hours & 6 & 86.60 & 28.43 \\
\hline
\end{tabular}

Table 10. Description of correlation of aggression score on the basis of number of hours of television watching

\begin{tabular}{llll}
\hline Variables & $\mathrm{df}$ & $\mathrm{t}$ value & Significance \\
\hline 0-2 hours \& 2-4 hours & 192 & 0.049 & Not significant \\
0-2 hours \& 4-6 hours & 138 & 0.073 & Not significant \\
2-4 hours \& 4-6 hours & 64 & 0.372 & Not significant \\
\hline
\end{tabular}

Observation of the value of Table 9 and table 10 shows that the correlation between television viewing and aggression score for 0-2 hours and 2-4 hours of television viewing degree of freedom (df) is 192 and $t$ value is 0.049 and it is not significant at 0.5 level.

The correlation between television viewing and aggression score for 2-4 hours and 4-6 hours of television viewing degree of freedom (df) is 138 and $t$ value is 0.073 and it is not significant at 0.5 level.

The correlation between television viewing and aggression score for 2-4 hours and 4-6 hours of television viewing degree of freedom (df) is 64 and $t$ value is 0.049 and it is not significant at 0.5 level.

It means that there is no relationship between the television viewing hour and aggressive behavior of secondary school students. But when we interpret table 9 it shows that mean value of aggression score of secondary school students who watch television 0-2 hours is less than 4-6 hours of television watching and mean value of aggression score of secondary school students who watch television 2-4 hours is less than 6-4 hours of television watching. It clearly indicates that students who watch more television are more aggressive. As the hour of television watching increases the aggression level of students are also increases.

\subsubsection{On the Basis of Parental Guidance}

Observation of the value of Table 11 and 12 shows that the correlation between parental guidance in television viewing and aggression score. In the case for sometimes and mostly Parental guidance in television viewing and aggression scores correlation shows degree of freedom (df) is 75 and t-value is 0.76 and it is not significant at 0.5 level.

In the case for sometimes and always Parental guidance in television viewing and aggression scores correlation shows degree of freedom (df) is 70 and t-value is 0.24 and it is not significant at 0.5 level.

In the case for sometimes and never Parental guidance in television viewing and aggression scores correlation shows degree of freedom (df) is 77 and t-value is 0.711 and it is not significant at 0.5 level.

In the case for mostly and always Parental guidance in television viewing and aggression scores correlation shows degree of freedom (df) is 19 and t-value is 0.24 and it is not significant at 0.5 level.

In the case for mostly and never Parental guidance in television viewing and aggression scores correlation shows degree of freedom (df) is 26 and t-value is 0.96 and it is not significant at 0.5 level. 
In the case for always and never Parental guidance in television viewing and aggression scores correlation shows degree of freedom (df) is 21 and t-value is 0.26 and it is not significant at 0.5 level.

Data clearly shows there in no significant relationship between parental guidance in television viewing and aggressive behavior of secondary school students.

Table 11. Description of aggression score on the basis of parental guidance

\begin{tabular}{llll}
\hline Parental guidance & $\mathrm{N}$ & $\mathrm{M}$ & S.D. \\
\hline Sometimes & 128 & 66.00 & 23.66 \\
Mostly & 26 & 63.84 & 23.67 \\
Always & 16 & 67.37 & 22.87 \\
Never & 30 & 63.40 & 27.40 \\
\hline
\end{tabular}

Table 12. Description of correlation of aggression score on the basis of availability of parental guidance

\begin{tabular}{llll}
\hline Variables & df & t- value & Significance \\
\hline Sometimes \& Mostly & 152 & 0.76 & Not significant \\
Sometimes \& Always & 14 & 0.24 & Not significant \\
Sometimes \& Never & 156 & 0.71 & Not significant \\
Mostly \& Always & 40 & 0.24 & Not significant \\
Mostly \& Never & 54 & 0.96 & Not significant \\
Always \& Never & 34 & 0.26 & Not significant \\
\hline
\end{tabular}

3.3.3 On the Basis of Category of Programs

Table 13. Description of aggression score on the basis of category of programs

\begin{tabular}{llll}
\hline Categories of Television programs & $\mathrm{N}$ & $\mathrm{M}$ & S.D \\
\hline General Informational & 44 & 60.36 & 16.45 \\
Entertainment & 60 & 73.03 & 27.67 \\
Educational & 96 & 64.52 & 23.97 \\
\hline
\end{tabular}

Table 14. Description of correlation of aggression score on the basis of category of programs

\begin{tabular}{llll}
\hline Variables & $\mathrm{df}$ & $\mathrm{t}$ value & Significance \\
\hline General Informational \& entertainment & 102 & 0.061 & Not significant \\
General Informational \& educational & 138 & 0.46 & Not significant \\
Entertainment \& Educational & 154 & 0.15 & Not significant \\
\hline
\end{tabular}

Observation of the value of Table 13 and 14 shows the correlation between categories of television programs and aggression scores.

In the case of General informational and entertainment television programs degree of freedom (df) is 102 and $t$ value is 0.061 and it is not significant at 0.5 level.

The correlation between General informational \& educational television programs and aggression score degree of freedom (df) is 138 and $t$ value is 0.46 and it is not significant at 0.5 level.

The correlation between Entertainment \& educational television programs and aggression score degree of freedom (df) is 154 and t value is 0.15 and it is not significant at 0.5 level. 
Result shows that there is no significance relationship between categories of television programs and aggression behavior of secondary school students. But the mean of entertainment television programs is higher than another categories and it indicates that those students who like to watch entertainment television program is slightly more aggressive than other students.

3.3.4 On The Basis of Cause of Watching Television

Table 15. Description of aggression score on the basis of cause of watching television

\begin{tabular}{llll}
\hline Cause of watching television & $\mathrm{N}$ & $\mathrm{M}$ & S.D \\
\hline Entertainment & 30 & 79.66 & 27.88 \\
Information & 96 & 63.23 & 23.96 \\
Learning & 74 & 64.59 & 21.48 \\
\hline
\end{tabular}

Table 16. Description of correlation of aggression score on the basis of cause of watching television

\begin{tabular}{llll}
\hline Variables & $\mathrm{df}$ & $\mathrm{t}$ value & Significance \\
\hline Entertainment \& information & 124 & 0.03 & Not significant \\
Entertainment \& learning & 102 & 0.40 & Not significant \\
Information \& learning & 168 & 0.78 & Not significant \\
\hline
\end{tabular}

Observation of the value of Table 15 and 16 shows the correlation between cause for watching television programs and aggression score.

In the case of Entertainment and information degree of freedom (df) is 124 and t value is 0.03 and it is not significant at 0.5 level.

The correlation between cause of Entertainment and learning degree of freedom (df) is 102 and $t$ value is 0.40 and it is not significant at 0.5 level.

The correlation between information and learning degree of freedom (df) is 168 and $t$ value is 0.78 and it is not significant at 0.5 level. And it shows there is no significant relationship between cause of television watching and aggression of secondary school students.

But the mean of in the case where the cause is entertainment for watching television programs are higher than another categories and it indicates that those students who like to watch entertainment television program is slightly more aggressive than other students.

3.3.5 On the Basis of Favorite News Programs

Table 17. Description of aggression score on the basis of favorite news programs

\begin{tabular}{llll}
\hline Favorite News programs & $\mathrm{N}$ & $\mathrm{M}$ & S.D \\
\hline Political News & 68 & 61.38 & 22.31 \\
Sensational News & 36 & 79.72 & 17.33 \\
Sports News & 76 & 64.42 & 24.82 \\
Weather News & 20 & 64.60 & 30.94 \\
\hline
\end{tabular}

Observation of the value of Table 17 and table 18 shows that the correlation between favorite news program and aggression score. In the case for Political news\& Sensational news correlation shows degree of freedom (df) is 102 and t-value is 0.0038 and it is not significant at 0.5 level.

In the case for Political news\& Sports news correlation shows degree of freedom (df) is 142 and t-value is 0.588 and it is not significant at 0.5 level. 
In the case for Political news \& weather news correlation shows degree of freedom (df) is 86 and t-value is 0.71 and it is not significant at 0.5 level.

In the case for Sensational news \& sports news correlation shows degree of freedom (df) is 110 and t-value is 0.22 and it is not significant at 0.5 level.

In the case for Sensational news \& weather news correlation shows degree of freedom (df) is 54 and $t$-value is 0.10 and it is not significant at 0.5 level.

In the case for Sensational news \& weather news correlation shows degree of freedom (df) is 94 and $t$-value is 0.98 and it is not significant at 0.5 level.

Data clearly shows there in no significant relationship between favorite news program and aggressive behavior of secondary school students.

Table 18. Description of correlation of Aggression score on the basis of favorite news programs

\begin{tabular}{llll}
\hline Variables & $\mathrm{df}$ & t- value & Significance \\
\hline Political news \& Sensational news & 102 & 0.003 & Not significant \\
Political news \& Sports news & 142 & 0.588 & Not significant \\
Political news \& Weather news & 86 & 0.71 & Not significant \\
Sensational news \& Sports news & 110 & 0.02 & Not significant \\
Sensational news \& Weather news & 54 & 0.10 & Not significant \\
Sports news \& Weather news & 94 & 0.98 & Not significant \\
\hline
\end{tabular}

\section{Conclusions}

Findings of the investigation reveals that TV program viewing habits are not much among secondary school students on the basis of gender and locality but taste of TV viewing habits are differ. Most of students watch TV for their learning and educational purposes. It is a good sign. Both male and female students are not significantly differ on the Aggression but on the basis of high mean value boys declared as high aggressive rather than girls. It is due to innate tendency. However this investigation did not find any significant evidence that TV viewing affects aggressive behavior of students significantly. But is clear that student who watch more entertainment programs have more aggression it means they are watching something in the name of entertainment which is increasing their aggression.

\section{Acknowledgements}

Investigator shows deep thanks to Mr. Jamal Ahmad, alumni of MANUU, College of Teacher Education, Darbhanga for his help in collection of data and organizing this research.

\section{References}

Anderson, C. A., \& Bushman, B. J. (2002a). Human aggression. Annual Reviews Psychology, 53, $27-51$. http://dx.doi.org/10.1146/annurev.psych.53.100901.135231

Anderson, C. A., \& Bushman, B. J. (2002b). The effects of media violence on society. Science, 295, 2377-2379. http://dx.doi.org/10.1126/science.1070765

Bandura, A., Ross, D., \& Ross, S. (1963). Imitation of film-mediated aggressive models. Journal of Abnormal and Social Psychology, 66, 3-11. http://dx.doi.org/10.1037/h0048687

Bushman, B. J., \& Anderson, C. A. (2001). Media violence and the American public: Scientific facts versus media misinformation. American Psychologist, 56, 477-489. http://dx.doi.org/10.1037/0003-066X.56.6-7.477

Dimitri, A. C., \& Zimmerman, F. J. (2007). Violent television viewing during preschool is associated with antisocial behavior during school age. Pediatrics, 120, 993-999. http://dx.doi.org/10.1542/peds.2006-3244

Freedman, J. L. (1984). Effect of television violence on aggressiveness. Psychological Bulletin, 96, 227-246. http://dx.doi.org/10.1037/0033-2909.96.2.227

Freedman, J. L. (2002). Media violence and its effect on aggression: Assessing the scientific evidence. Toronto: University of Toronto Press. 
Geen, R. G. (1983). Aggression and television violence. In R. G. Geen, \& E. L. Donnerstein (Eds.), Aggression: Theoretical and empirical reviews (pp. 103-125). New York: Academic Press.

Heath, L., Kruttschnitt, C., \& Ward, D. (1986). Television and violent criminal behavior: Beyond the bobo doll. Victims and Violence, 1(3), 177-191.

Krcmar, M., \& Hight, A. (2007). The development of aggressive mental models in young children. Media Psychology, 10, 250-269. http://dx.doi.org/10.1080/15213260701375652

Zillmann, D. (1998). Connections between sexuality and aggression. Mahwah NJ: Lawrence Erlbaum Associates.

\section{Copyrights}

Copyright for this article is retained by the author(s), with first publication rights granted to the journal.

This is an open-access article distributed under the terms and conditions of the Creative Commons Attribution license (http://creativecommons.org/licenses/by/3.0/). 